ANALYSIS OF AN 80 GALLON RADIOACTIVE WASTE

PACKAGE RETRIEVED FROM THE ATLANTIC OCEAN

P. Colombo

Apri1 1977

Prepared for the OFFICE OF RADIATION PROGRAMS

UNITED STATES ENVIRONMENTAL PROTECTION AGENCY

INFORMAL REPORT

PROCESS TECHNOLOGY DIVISION

B R O O K H A V E N N A T I O N A L L A. B O R A T O R Y

A S S O C I A T E D U N I V E R S I T I E S, I N C.

U P T O N, N E W Y O R K 11973

Under Contract No. EY-76-C-02-0016 with the

UNITED STATES ENERGY RESEARCH AND DEVELOPMENT ADMINISTRATION 
INTRODUCTION

This progress report summarizes studies performed at Brookhaven National Laboratory (BNL) on the properties of a radioactive waste package recovered from the floor of the Atlantic Ocean 2800 meter radioactive waste disposal site. The recovery was made during DEEPSEA SURVEY OPERATION NO. 5, as part of a comprehensive study of disused deepsea radioactive disposal sites by the Office of Radiation Programs of the Environmental Protection Agency. A major objective of this study is to assess the effectiveness of past packaging techniques relevant to the isolation of radionuclides from the ocean environment over the period of time they remain potentially hazardous. For this purpose, a typical radioactive waste package which had previously been located and identified through the use of the deep sea submersible ALVIN was recovered aboard the R.V. CAPE HENLOPEN, 31 July 1976.

The package was recovered from the NW quadrant of the 28 meter Atlantic site and consists of an 80 gallon mild steel drum filled with a solidified mixture of concrete and radioactive materials.

\section{Package History}

The following is legibly inscribed on the open end concrete face of the drum:

\begin{tabular}{|c|c|}
\hline DATE & 61 \\
\hline \multicolumn{2}{|c|}{ DE, ACMLC } \\
\hline $\mathrm{Mr} / \mathrm{Hr} / \mathrm{S}$ & -40 \\
\hline $\mathrm{Mr} / \mathrm{Hr} / \mathrm{M}$ & -3 \\
\hline ISO & $-C 0-60$ \\
\hline WT. & 1682 \\
\hline $\mathrm{CF}$ & 9.6 \\
\hline PKG & 28 \\
\hline
\end{tabular}

Additional information supplied by the site where the waste was packaged indicates that the 80 gallon drum was formed by welding one half of a 55 gallon drum to the end of another 55 gallon drum to increase its length. The added length was necessary to accommodate a sealed stainless 
tube used to encapsulate demineralized resin or filter material containing C0-60. This tube was centered in the 80 gallon mild steel drum and the surrounding space was filled with concrete containing radioactive cesium and possibly co-60.

\section{Handling and Preparation}

Following recovery of the 80 gallon drum aboard the R.V. CAPE HENLOPEN, it was encapsulated in a jet engine shipping container under a positive pressure of argon gas $(760 \mathrm{~mm})$ to inhibit further corrosion prior to examination at BNL.

The container arrived at BNL 6 August 1976, and it remained unopened until 10 November 1976, at which time EPA gave approval to commence with the corrosion and matrix degradation studies.

The sealed jet container was opened and the 80 gallon drum was transferred to a "hot-cell" for sampling and coring operations. In general, it appeared that little or no rust had formed on the surface of the container during the storage period. The package, however, had drained 7.5 liters of water which collected in the jet container. Radiochemical analysis of the water using a $\mathrm{Ge}(\mathrm{Li})$ detector measured the following radionuclides:

$$
\begin{array}{ll}
\text { Cesium-137 } & 3.40 \times 10^{-4} \mu \mathrm{Ci} / \mathrm{ml} \\
\text { Cesium-134 } & 1.70 \times 10^{-5} \mu \mathrm{Ci} / \mathrm{ml} \\
\text { Cobalt-60 } & \sim 10^{-6}-10^{-7} \mu \mathrm{Ci} / \mathrm{ml}
\end{array}
$$

The drum was radiographed to determine the size and position of the sealed tube imbedded in the concrete. Measurements indicate that the tube is approximately centered in the drum with an overall length of $38^{\prime \prime}$ and a diameter of $6 "$. One end of the tube has an 8 "flange, bolted to make a seal.

\section{Corrosion Analysis of the Outer Metal Container}

On November 15, 1976, more than 40 metal samples were trepanned and chiselled from the outer lining of the package. Some additional corrosion scale was also sampled. At the time of cutting, a radioactivity level for 
each sample was determined. The samples were stored in dessicators over anhydrous $\mathrm{CaSO}_{4}$ in preparation for analysis.

The corrosion analysis of the carbon steel outer drum has progressed in four areas on analysis.

a. Visual observation

b. Metallographic analysis

c. Scanning electron microscopic analysis

d. Qualitative chemical microanalysis

A detailed report of the results of the corrosion analysis pertaining to the carbon steel outer container is forthcoming in a final report. Accomplishments to date, however, are summarized below:

A. Visual Observation

A complete set of photographs indexed with respect to the container coordinates recorded the appearance of the recovered container. This observation allowed an overall assessment of the corrosion attack. Points of specific attack were located and examined.

\section{B. Metallographic Analysis}

The metallographic analysis has continued along two paths. First, the thickness of the metallographic cross sections sampled uniformly along the length of the drum have been measured and tabulated with respect to the container coordinates. This allows a quantitative evaluation of the overall attack as well as an indication of its position dependence. Second, the mechanisms of specific corrosive attack are probed by the detailed metallography of selected cross sections. This work provides important information on the metallic microstructure and the interfacial morphologies at points of specific attack. To date, metallographs specific to isolated pits, general pitting, welds, chimes, folds, and the concrete/ metal interface have been made.

\section{Scanning Electron Microscopic Analysis}

Scanning electron micrographs of some microscopic surface features of the carbon steel container have been made. They illustrate the morphology of surface deposits; and when produced in conjunction with the non-dispersive 
$x$-ray fluorescence analyzer, they have provided a qualitative chemical description of these deposits. To date, micrographs of the relatively unattacked central region and of the concrete/metal interface have been made. Adherent calcium and silicon rich deposits on the exterior surface have also been observed. Any involvement of these features with a corrosion mechanism has yet to be determined.

\section{Qualitative Chemical Microanalysis}

Scrapings of the loose material changing to the outer metal container were sampled and their respective positions documented. X-ray diffraction spectra of a selected number of these samples have been made. Although a complete analysis has yet to be made, these spectra indicate that the predominant crystalline species are $\alpha-\mathrm{Fe}_{2} \mathrm{O}_{3}$ and $\alpha$ and $\gamma-\mathrm{FeOOH}$.

In addition, $x$-ray fluorescence spectroscopic analyses as well as qualitative wet chemical analyses of selected samples of the loose material have been performed.

\section{Concrete Analysis}

To facilitate sample coring and for visual observation, the entire concrete monolith was exposed by removing the outer metal container.

\section{A. Visual Observation}

The concrete monolith was indexed with respect to the outer container coordinates and photographed. There was no visible indication of appreciable concrete degradation.

\section{B. Coring and Sampling}

Approximately 12 concrete cores have been obtained for radiochemical analysis and for chemical stability studies. The cores were drilled dry to a depth of $6^{\prime \prime}$ to $8^{\prime \prime}$ using a $2^{\prime \prime}$ diameter diamond masonry bit. The use of water as a lubricant was eliminated during core drilling to minimize loss of radionuclides. 


\section{Chemical Analysis}

Core samples are being prepared for x-ray diffraction studies and for wet chemical analysis. Samples of concrete have been dissolved to determine the radionuclides present and the distribution of these radionuclides as a function of position in the concrete matrix. Selective samples are being prepared for static leach testing in seawater.

5. Inner Tube

When a sufficient number of cores have been drilled for chemical and physical testing, the imbedded tube will be removed for metallurgical, chemical and radiochemical analysis. 